\title{
SIMULATION OF SURFACE RUNOFF FOR UPPER TAPI SUBCATCHMENT AREA (BURHANPUR WATERSHED) USING SWAT
}

\author{
Vikash Shivhare $^{\mathrm{a}}$, M K Goel ${ }^{\mathrm{b}}$, C K Singh ${ }^{\mathrm{a}}$ \\ a Dept. of Natural Resource, TERI University, Vasant Kunj, New Delhi, India - chander.singh@ @eriuniversity.ac.in, \\ vikashshivhare123@gmail.com \\ ${ }^{\mathrm{b}}$ Division of Water Resource, National Institute of Hydrology, Roorkee, India - goel.mk1@ gmail.com
}

Commission VI, WG VI/4

KEY WORDS: Watershed, Surface Runoff, SWAT, GIS, Tapi

\begin{abstract}
:
Water related activity that takes place in one part of a river basin may have consequence in the other part. Any plan related to inter basin transfer of water from a water surplus basin to a deficit basin has to take into account the water availability and demands under the present and future scenarios of water use. Watershed is a hydrologic unit where all stream exit from the common outlet. In the present study, Tapi subcatchment area (Burhanpur watershed) located in inter-state basin of Madhya Pradesh and Maharashtra, India, is selected for the estimation of surface runoff using SWAT model. The SWAT works in conjunction with Arc GIS 9.3. Various parameters Digital Elevation Model (DEM), slope derived from DEM, Landuse/Landcover (LULC) and NBSSLUP soil data and temporal data for temperature and precipitation was used as input for the model to predict runoff at the catchment outlet. The model was run from the year 1992 to 1997. The performance of the model in terms of simulated runoff was evaluated using statistical method and compared simulated monthly flow with the observed monthly flow values from 1992 to 1996 to a significant extent. The coefficient of determination $\left(\mathrm{R}^{2}\right)$ for the monthly runoff values for 1992 to 1996 was observed to be $0.82,0.68,0.92,0.69$.
\end{abstract}

\section{INTRODUCTION}

Water is a transparent fluid which forms the streams, lakes, ocean and rain and is one of the major constituents of the fluids of living beings. Hydrological research deals with the distribution and circulation of water with environment (chow et al., Subramanian, 2004). A watershed is a hydrologic unit or an area of land from which water drains, running downhill, to a shared destination or which produce water as the end product by interaction of precipitation and the land surface (Jain, SK et al., 2010). A watershed is a catchment basin that is bound with topographic features. A catchment area can be very small, it can be few hectares, or it may cover an enormous area, as for example the Ganga and the Brahmaputra basin. The total amount of water that falls as rains within a catchment area will either flow as surface runoff in the river which drains the basin or sinks into the ground to become ground water. Surface water and ground water is used for agricultural, industrial and domestic purposes(Goel et al., 2008). Remotely sensed data provides valuable and real-time spatial information on natural resources and physical parameter. GIS is an effective tool in watershed modeling as remote sensing derived information can be well integrated with the conventional database for estimating runoff which can help in planning suitable soil and water conservation measures. Since the modeling of runoff is essential for sustainable development, it is desirable that some suitable methods are used for quantifying the hydrological parameter from all parts of the watershed. Use of mathematical models for hydrologic evolution of watershed is the current trend along with extraction of watershed parameters using remote sensing and Geographical Information System (Jain, SK et al., 2010). The current study was undertaken on the application of the SWAT model which integrates the GIS information with attribute database to estimate the runoff. The model application has been demonstrated for the Upper part of Tapi sub catchment area in Burhanpur watershed.

\subsection{The Study Area}

The Tapi River is the second largest west flowing river of India with its catchment area lying in the States of Madhya Pradesh, Maharashtra and Gujarat States. The river originates in the highlands of the Satpura hills near Multai town in Betul district of Madhya Pradesh and finds its outlet in the Arabian Sea. The Tapi river basin comprises of three basins, namely upper Tapi, Middle Tapi, and Lower Tapi basin. The whole Tapi basin is covered under an area of $65,145 \mathrm{sq}$. km out of which 29,430 sq. $\mathrm{km}$ and 25,320 sq. $\mathrm{km}$ are covered in upper and middle Tapi basins. The study area in the present study is a sub-catchment of Upper Tapi River Basin, namely Burhanpur watershed. Burhanpur watershed starts from Multai town in Betul district up to Burhanpur District. This watershed is covered in two states of Madhya Pradesh and Maharashtra, out of which major part is covered in Madhya Pradesh (Narasayya et al.2013). The study area (Figure 1) extends from $21^{\circ} 22^{\prime}$ to $21^{\circ} 44^{\prime}$ North latitude $76^{\circ} 6^{\prime}$ to $78^{\circ} 14^{\prime}$ East longitude. Total geographic area of Burhanpur watershed under study is 9364 sq. km. It is situated in the southern border of Madhya Pradesh near the bank of Tapi River. The study area has semi arid climatic condition with a maximum temperature in May of around $45^{\circ} \mathrm{c}$ and a minimum temperature of around $8^{\circ} \mathrm{c}$ during the month of December. The average annual rainfall is around $830 \mathrm{~mm}$ in this watershed. The total length of Tapi river that flows in Burhanpur watershed from its source to outlet point at Burhanpur is nearly $282 \mathrm{~km}$. The soils in the Tapi basin can be broadly classified into 3 groups, viz. 1) coarse shallow soils, 2) medium black soils, and 3) deep black soils. Coarse shallow soils have developed from the basaltic Deccan traps and have depth generally between 25 to $50 \mathrm{~cm}$ and more. Their texture 
from surface to sub-surface varies from silt-loam to clay. Major part of the land use in Tapi sub catchment is covered by the forests and the cultivated area.

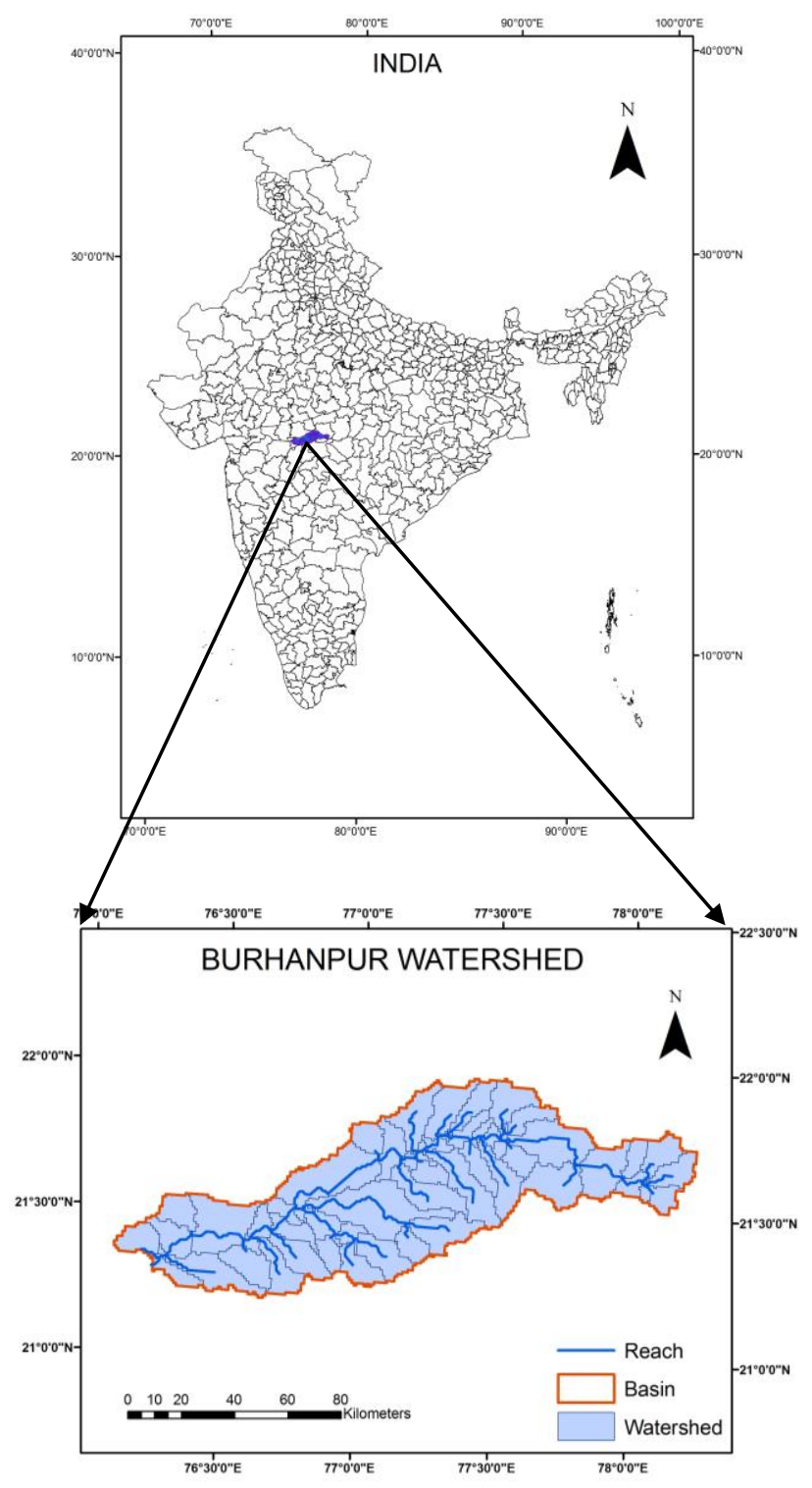

Figure 1. The Study Area

\subsection{ArcSWAT Model}

SWAT is the acronym for SOIL AND WATER ASSESMENT TOOL, a river basin or watershed scale model developed by Dr.Jeff Arnold and jointly developed by the United States Department of Agriculture - Agriculture Research Services (USDA-ARS) and Agriculture Experiment Station in temple, TEXAS. The model was developed to predict the impact of land management practices on water, sediment and agriculture chemical yields in large complex watershed with varying soil, land use and management conditions over a long period of time. SWAT is a physically based, continuous time model for long term simulation which originated from an agricultural model. Water balance is the driving force behind everything that happens in a watershed to accurately predict the hydrological cycle, sediment or nutrient movement. Simulation of hydrology of a watershed is divided in two categories:
Land phase of the hydrological cycle: it controls the amount of water, sediment etc. to the main channel in each sub-basin.

The water, or routing phase of the hydrologic cycle: movement of water, sediments etc. through the channel network of the watershed to the outlet.

The computational components of SWAT can be grouped into different division hydrology, weather, sedimentation, soil temperature, crop growth, nutrients, pesticide and agricultural management (SWAT Theoretical Documentation, 2009). The SWAT model uses physically based inputs such as weather variable, soil properties, topography, vegetation and land management practices occurring in the catchment. The physical process associated with water flow, sediment transport, crop growth, nutrient cycling etc. are directly modeled by SWAT. The hydrologic cycle as simulated by SWAT is based on the water balance equation (all water units in depth terms in $\mathrm{mm}$ )

$\mathbf{S W t}=\mathrm{SW}_{0}+\sum_{\mathrm{i}=1}^{\mathrm{n}}\left(\right.$ Rday - Qsurf - Ea $\left.-\mathrm{W}_{\text {seep }}-\mathbf{Q}_{\mathrm{gW}}\right)$

where, $S W t$ is the final soil water content $(\mathrm{mm} \mathrm{H} 2 \mathrm{O}), S W o$ is the initial soil water content $(\mathrm{mm} \mathrm{H2O}), t$ is time in days, $R$ day is amount of precipitation on day $i(\mathrm{~mm} \mathrm{H} 2 \mathrm{O}), Q \operatorname{surf}$ is the amount of surface runoff on day $i(\mathrm{~mm} \mathrm{H} 2 \mathrm{O}), E a$ is the amount of evapotranspiration on day $i(\mathrm{~mm} \mathrm{H} 2 \mathrm{O})$, wseep is the amount of percolation and bypass exiting the soil profile bottom on day $i$ (mm H2O), $Q g w$ is the amount of return flow on day $i(\mathrm{~mm}$ $\mathrm{H} 2 \mathrm{O})$.

SWAT model uses hourly and daily time step data to calculate surface runoff. The Green \& Ampt method is used for hourly data and an empirical SCS Curve number is used for daily computation.SCS method stands for Soil Conservation Service method which is widely used for estimating flood on small to medium sized unguaged drainage basins. It was developed originally as a procedure to estimate runoff volume and peak discharge for design of soil conservation works and flood control project (Maidment, The Handbook of Hydrology). The SWAT model estimates runoff volume by using the Soil Conservation Service (SCS) curve number technique (USDA, 1972). In SWAT model, a basin is delineated into various subbasins, which are further subdivided into HRUs which stands for Hydrological Response Unit. HRUs divide the sub basin in to the area of similar land use, soil type and slope. One can eliminate the minor land use and soil type in the basin.

GIS plays an important role to develop various kind of physically based river basin Hydrological models. It has become in Hydrology for assessing the impact. Various studies have been done in the hydrological modeling using SWAT by Indian researcher.

Tripathi et al. The authors applied the SWAT model for hydrological modeling of a small watershed using generated rainfall in eastern India. He applied the SWAT model for the Nagwan Watershed. The watershed has a drainage area of 92.46 sq. $\mathrm{km}$. The objective of their study was to simulate the runoff, sediment yield and water quality of watershed and to predict the effect of changing landuse and conservation practices on sediment yield within the area. Daily rainfall, runoff and sediment yield values of 8 years (1991-1998) were used for the study. Apart from that, climatic data, topographical map, land use map, and soil map were used in the study. In the study, simulated monthly average values using generated rainfall compared well with observed values during the monsoon season of the years 1991-1998 for surface runoff and sediment yields (Reshma et al.).Jain et al. 2010 applied the hydrological 
modeling for a Himalayan watershed using SWAT model. They applied the SWAT model for the estimation of runoff and sediment yield from Suni to Kasol, an intermediate watershed in Satluj River basin. They used the topographical data, land use map, soil map and climatic data for the application of the SWAT model. The daily runoff and sediment load data of two stations, namely Suni and Kasol were used for the years 1993 through 1997. They tested the statistical and graphical method to assess the capability of model in simulating the runoff and sediment yield from the study area. Khare et al. Applied the SWAT model on daily basis or monthly basis for predicting surface runoff from a Barinallah Watershed on the western hills in chamba district. The model was run and calibrated and validated for two years (2002 to 2003) using field measured discharge data of watershed. They found that the outcome of the study indicates effectiveness of the model for simulating the overflow is excellent (Narasayya et al.). Shrivastava et al. applied the SWAT model on daily and monthly basis for predicting surface runoff and sediment yield from a Chokharnala Watershed in eastern India. The model was run and verified for the initial phase of the monsoon season in the year 2002 using daily rainfall and air temperature. They found satisfactory or good agreement between observed and simulated runoff and sediment yields. The model capability to generate rainfall was evaluated for 10 years (1992-2001). Simic et al. Applied the model on SWAT based runoff modelling in complex catchment areas.

In view of the application of SWAT model to a number of study watersheds by Indian researchers, it was decided to apply the model for a part of the Tapi basin. The development of database for the study area and methodology adopted for the model application is discussed in subsequent section.

\section{METHODOLOGY}

\subsection{Database Development for the Study Area}

Spatial attribute and dynamic data was collected for the Tapi sub-catchment area (Burhanpur Watershed). Digital elevation model is one of themain input of SWAT. Tapi basin DEM was obtained from SRTM. Tapi basin DEM and thye location of the study area with respect to Tapi basin is shown in figure 2,3. The SRTM DEM for the Tapi basin was obtained at $90 \mathrm{~m}$ resolution. The elevation map was aggregated to $1000 \mathrm{~m}$ resolution by averaging the grid wise elevation using nearest neighbourhood method in LCC coordinate system(Figure 2). Out of the total Tapi basin ,only a part of upper Tapi basin (up to Burhanpur Watershed G \& D site) was considered in the study(Figure 3).

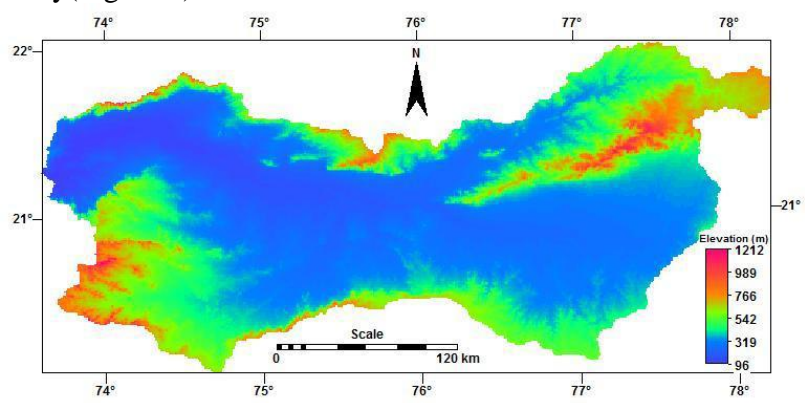

Figure 2. SRTM DEM of Tapi Basin Up to Ukai dam

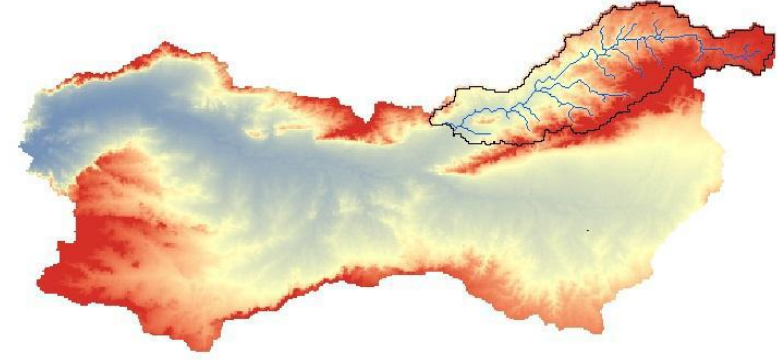

Figure3. Location of study area with respect to Tapi basin

Land use map is important consideration and critical input for the SWAT. It effect the generation of land flow, soil water storage, water demand for irrigation etc. Land use map was obtained from the Global Land Use Facility from the world wide website. The area surrounding the Tapi basin was extracted from the global land use map. Various land use categories and their coverage in the Watershed are shown in Figure 4 and Table 1.

\begin{tabular}{|l|l|l|l|}
\hline Landuse category & Code & Area (ha) & $\begin{array}{l}\text { percentage of } \\
\text { Watershed } \\
\text { Area }\end{array}$ \\
\hline Urban & URML & 3000 & 0.32 \\
\hline $\begin{array}{l}\text { Rainfed } \\
\text { Agriculture }\end{array}$ & CRDY & 290000 & 30.97 \\
\hline $\begin{array}{l}\text { Irrigated } \\
\text { Agriculture }\end{array}$ & CRIR & 170000 & 18.15 \\
\hline Forest & FOMI & 448400 & 47.89 \\
\hline Barren land & BSVG & 24900 & 2.66 \\
\hline Water Body & WATB & 100 & 0.01 \\
\hline
\end{tabular}

Table 1. Coverage of Landuse categories in the study

Soil plays an important role in various process of hydrological modeling. In ArcSWAT, various soil properties like soil texture, hydrolic conductivity, bulk density, water content are essential to make an input to the model. The soil map and it's physical properties for sub-catchment obtained from the NBSSLUP and used in the present study. Soils with texture sandy/sandy loam is considered as class A (High infiltration rate and low runoff potential), with texture silt loam/loam as class B (Moderate infiltration rate), with texture sandy clay loam as class $\mathrm{C}$ (low infiltration rate), and with texture clay loam/clay/silty clay as class D (very slow infiltration rate and high runoff potential). The soil map of the area is shown in Figure 5.

SWAT requires daily precipitation $(\mathrm{mm})$ and minimum, maximum temperature $\left({ }^{\circ} \mathrm{C}\right)$. Values for input may be read from records of observed data or they may be generated. The precipitation data table is used to store the precipitation for individual raingauge stations. Daily precipitation data for the year 1992 through 1997 was available. The rainfall is observed at 11 station namely Multai, Betul, Atner, Chicholi, Bhaindeshi, Chikhalda, Dharni, Akola, Khandwa, Burhanpur, and Jalgaon. monthly temperature data were available. Therefore, average monthly maximum and minimum temperature data for the Akola station has been transformed into daily values and used for the simulation analysis from June 1992 to May, 1996. 


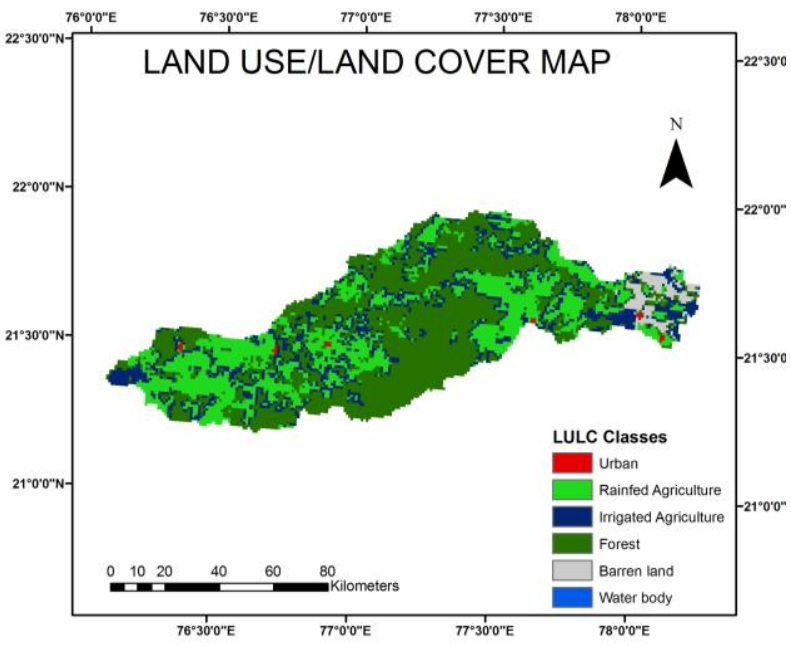

Figure 4. Land use Land cover Map of Tapi sub-basin

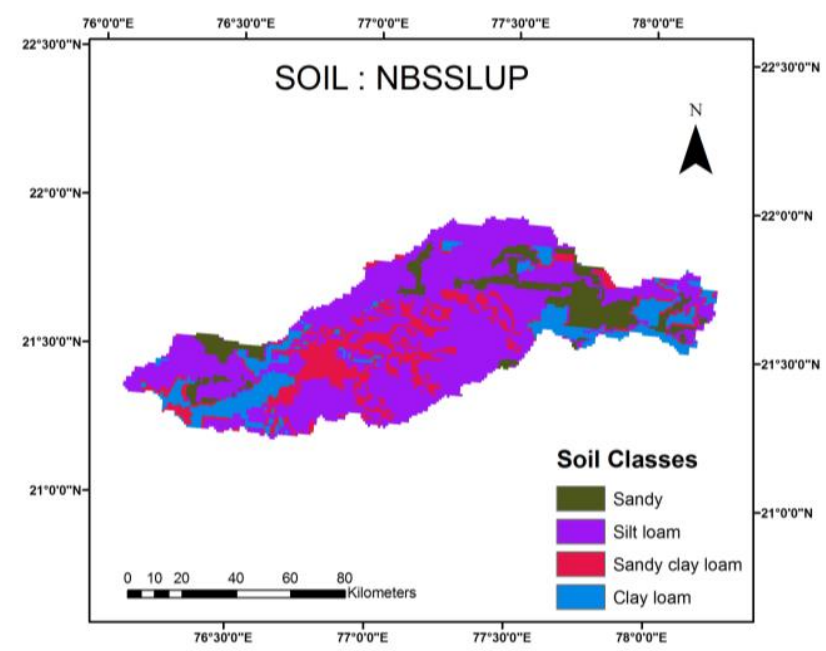

Figure5. Soil Map of Tapi basin

\subsection{Model Setup}

The entire database required by the SWAT model has been developed for the study area (Upper Tapi basin up to Burhanpur G \& D site) and the model has been setup for the area. The main procedure and various steps followed in model application are explained below: SWAT project setup, Watershed delineation, HRU Analysis, Write input table, Edit SWAT Input, SWAT Simulation. The methodology for the runoff modelling at the basin outlet using SWAT is depicted in flow chart (Figure 6).

SWAT automatically delineates a watershed into sub-watershed based on DEM. DEM was imported in the model and the mask is manually created in the model in order to extract out the Tapi sub-catchment area. The critical source area or the minimum drainage area required to form the origin of a stream was taken as 10,000 ha.Model Generated 56 sub-watershed of the Tapi sub catchment area. The outlet is defined at the location of monitoring station (Burhanpur G \& D site). Watershed was delineated for the present study and all parameters were calculated for each sub basin. The area delineated by the model was found to be 936400 ha. After that, two reservoir locations were defined in the basin. The Burhanpur watershed was delineated successfully as shown in Figure 7.

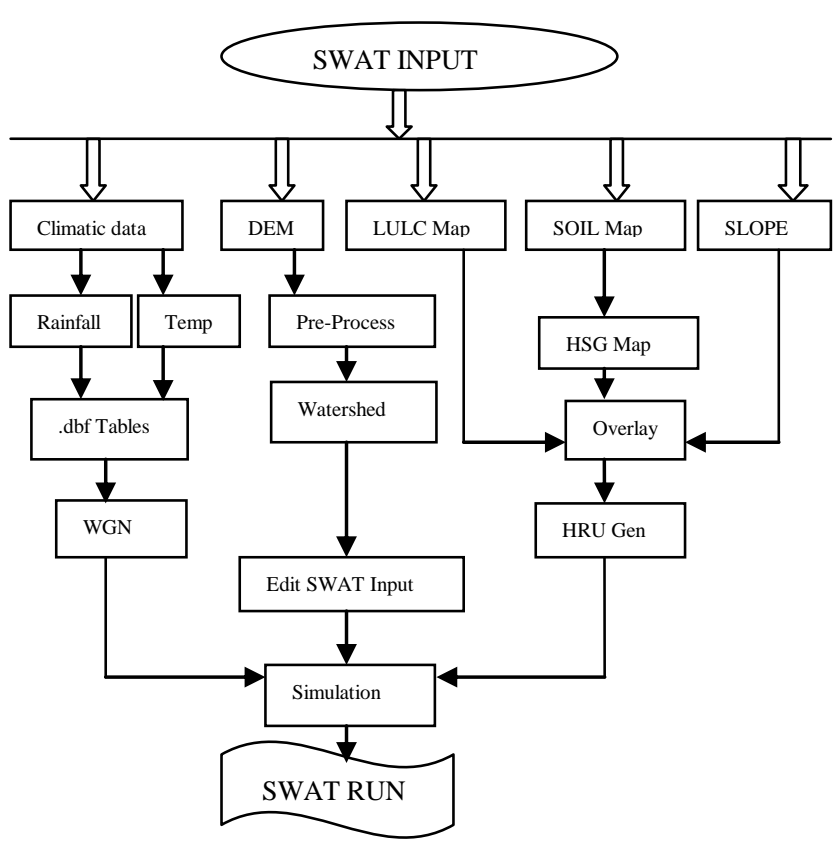

Figure6. ArcSWAT Methodology for rainfall-runoff modelling

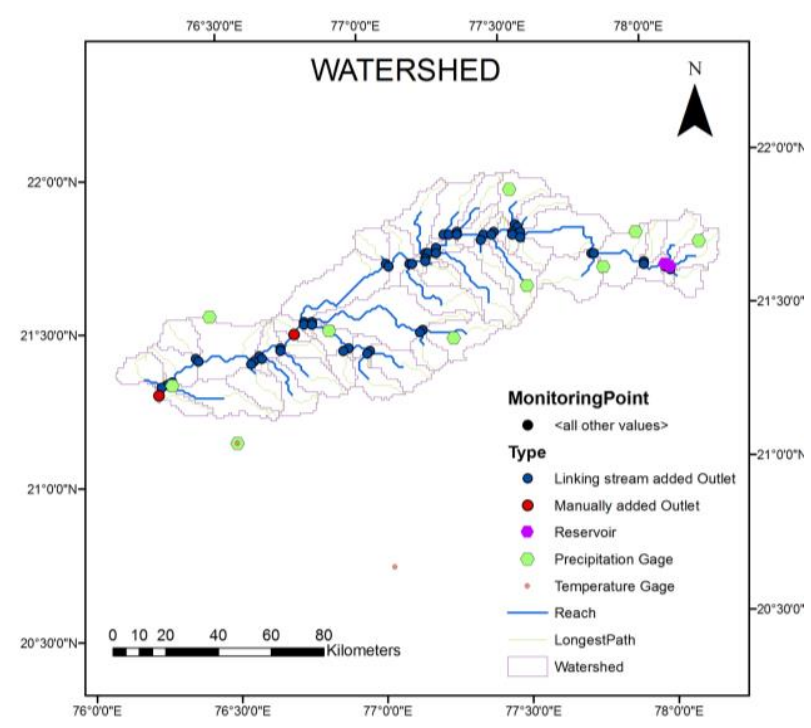

Figure7. Delineation of Watershed in ArcSWAT

HRUs are the Hydrological response unit that divides the watershed into various homogeneous units based on the land use, soil type, and slope at each grid. Hydrologic response units for each sub basin were created. SWAT requires land use and soil data to determine the HRUs for each sub-basin. The land use and soil map have been imported in the model. Land use category is used to specify the land use layer and soil look up table is used to specify the type of soil to be modeled for each category. in the soil layer, linked to the SWAT database and reclassified land use and soil map. The soil map reclassified the database in 4 hydrological soil group (HSG) named A, B, C, D 
based on their infiltration rate. The lulc map was also reclassified into 6 different categories The slope map is reclassified in 3 classes: a) $0-1.5 \%$, b) $1.5-3.0 \%$, and c) $>3$ $\%$ Reclassified slope map is shown in Figure 8.

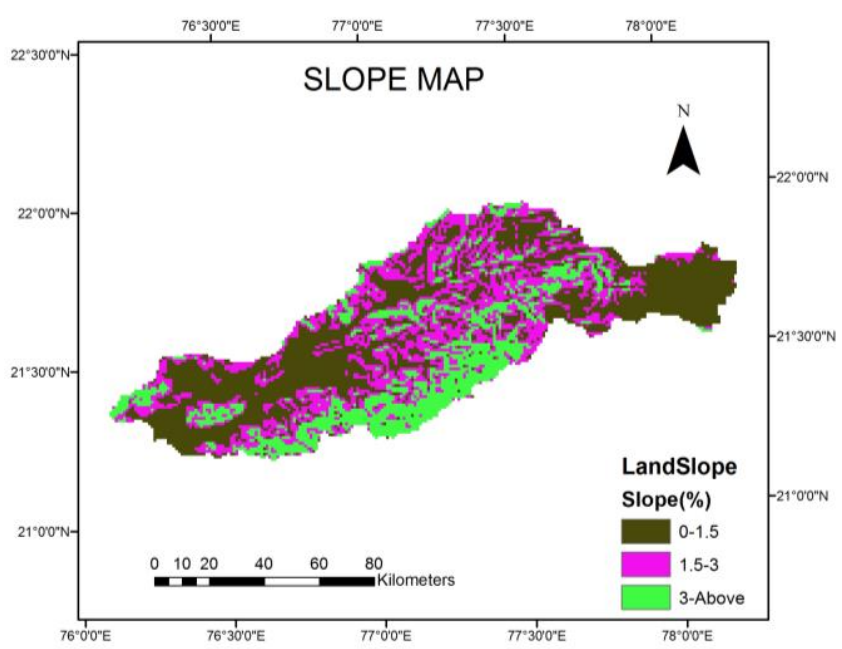

Figure8. Slope map of Burhanpur Watershed

Next, the land use, soil and slope maps were overlaid. To eliminate minor land use, soil and slope, threshold percentage method was adopted and 5\% threshold for land use, $10 \%$ threshold for both soil and slope were used. The HRUs were delineated and corresponding report was also generated by the model which specified the area of different HRUs in various sub-basins. A total of 656 HRUs were generated in the Burhanpur watershed. The model requires daily data for precipitation and temperature that is provided by the user in the .dbf format and is stored in the project database. Remaining necessary climatic data can be generated as the user specified .wgn file. For the present study, there was no temperature station within the watershed. However, two close-by meteorological stations, namely Akola and Jalgaon were used for the present study. Weather data like rainfall of 6 years of daily data from 1992 to 1997 in 11 rain gauge station Multai, Betul, Atner, Chicholi, Bhaindeshi, Chikhalda, Dharni, Akola, Khandwa, Burhanpur, Jalgaon and minimum and maximum temperature data of Akola and Jalgaon stations were utilized for the years 1992-1997. The climatic data for study periods were prepared in .dbf format and then imported in the SWAT model. After importing the climatic data the next step was to set up a few additional inputs for running the SWAT model. The characteristics of the soil data and the properties of the land use were defined in the model as per Indian condition. These input file were set up and edited as per the requirement and objective of the study. Next, reservoir input data was used to define the monthly outflow data from the reservoirs along with the monthly demands and desirable rule curve levels. In addition, the monthly domestic and agricultural water use data from surface and groundwater for domestic and agricultural purposes. The watershed parameters showing the characteristics of surface runoff was defined. The files were successfully rewritten and stored in personal geodatabase of the model. After this step, the model was run to simulate the surface runoff.

\subsection{Performance Evalution of the Model}

The model was evaluated in order to determine the performance that how the model, simulated value fitted with the observed value. Statistics techniques like the coefficient of determination is one of the method to assess the model performance and also estimate that at which level simulate value fitted with the observed value. It shows the best fitness and efficiency of the model. R square describes the proportion of the total variance in the measured data that can be explained by the model. It ranges from 0.0 to 1.0 . High values indicating better agreement.

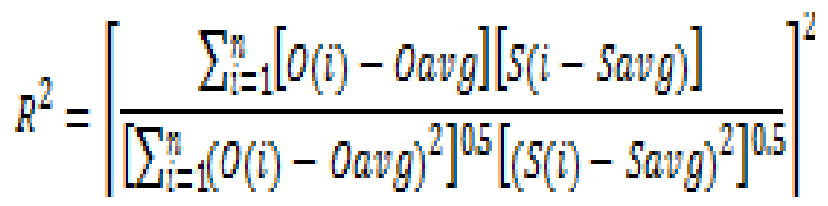

where, $O(i)$ is the ith observed parameter, Oavg is the mean of the observed parameters, $S(i)$ is the ith simulated parameter, Savg is the mean of model simulated parame-ters and $N$ is the total number of events.

\section{RESULT AND DISCUSSION}

\subsection{SWAT Simulation}

SWAT simulation has been done for the duration from January 01, 1992 to December 31, 1997. Skewed normal rainfall distribution option was selected. The SWAT model has been run for the current study and output was generated at monthly time step.

\subsection{Results of the SWAT}

The model was generated runoff series for the study area from January 01, 1992 to December 31, 1997 in depth units (mm). The same was converted to monthly volume in million cubic metres (MCM). Monthly observed flow volume at Burhanpur gauging site (in MCM) were available from June, 1992 to May, 1996. Therefore, the performance of the model in terms of simulated runoff was evaluated using statistical method and compared simulated monthly flow with the observed monthly flow values from 1992 to 1996 to a significant extent. The coefficient of determination $\left(R^{2}\right)$ for the monthly runoff values for 1992 to 1996 was observed to be $0.82,0.68,0.92,0.69$ respectively for runoff.The results are shown in Figure 9 (a, b, c, d). As can be seen in the analysis, monthly runoff value for the years 1992 to 1993 and 1994 to 1995 showed a better correlation than the other monthly values for the respective years.

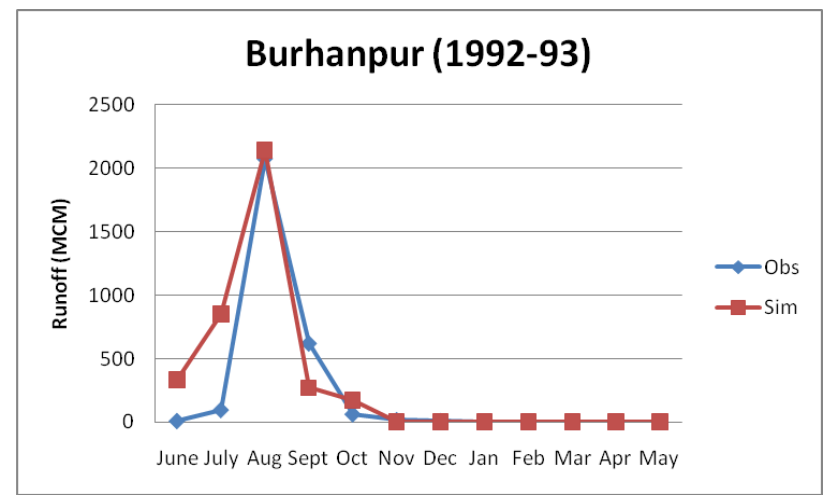

(a) 


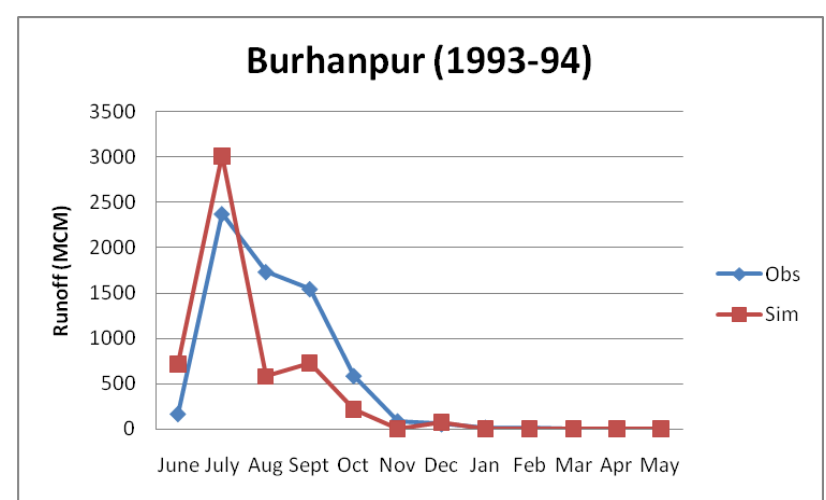

(b)

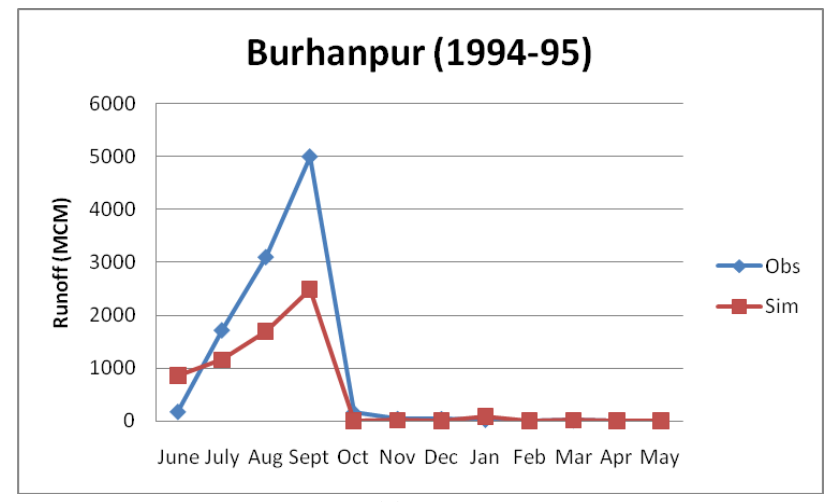

(c)

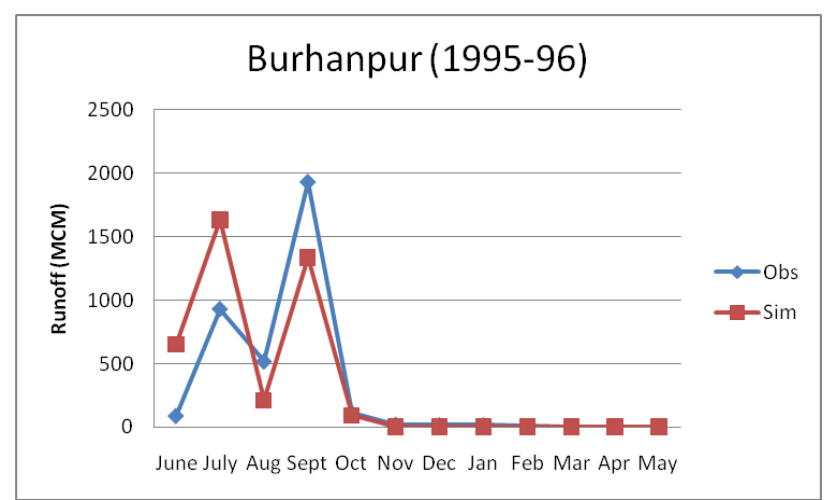

(d)

Figure 9. Comparison of Observed and Simulated flows $(\mathrm{a}, \mathrm{b}, \mathrm{c}, \mathrm{d})$

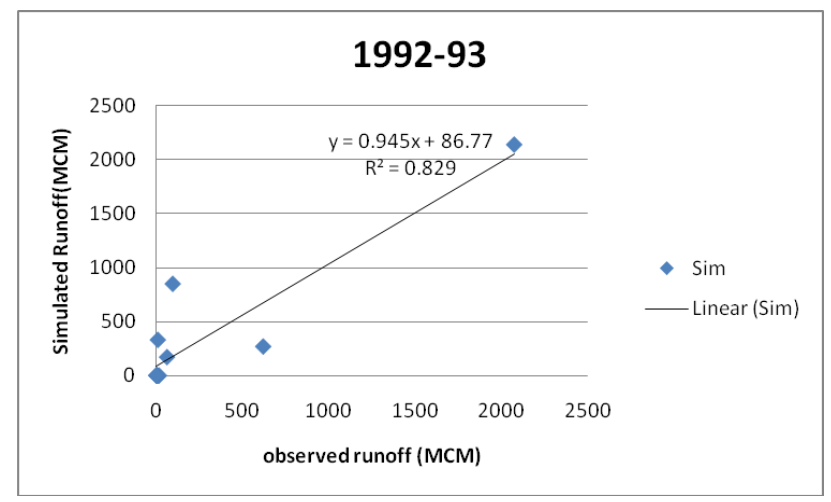

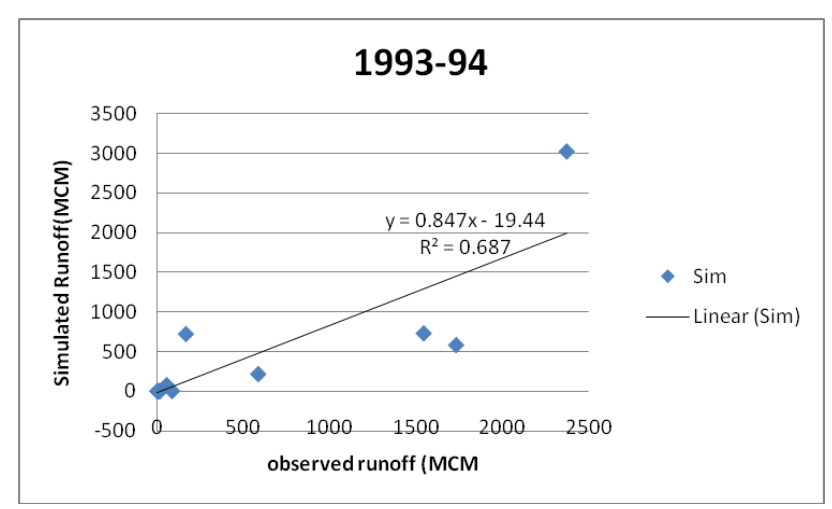
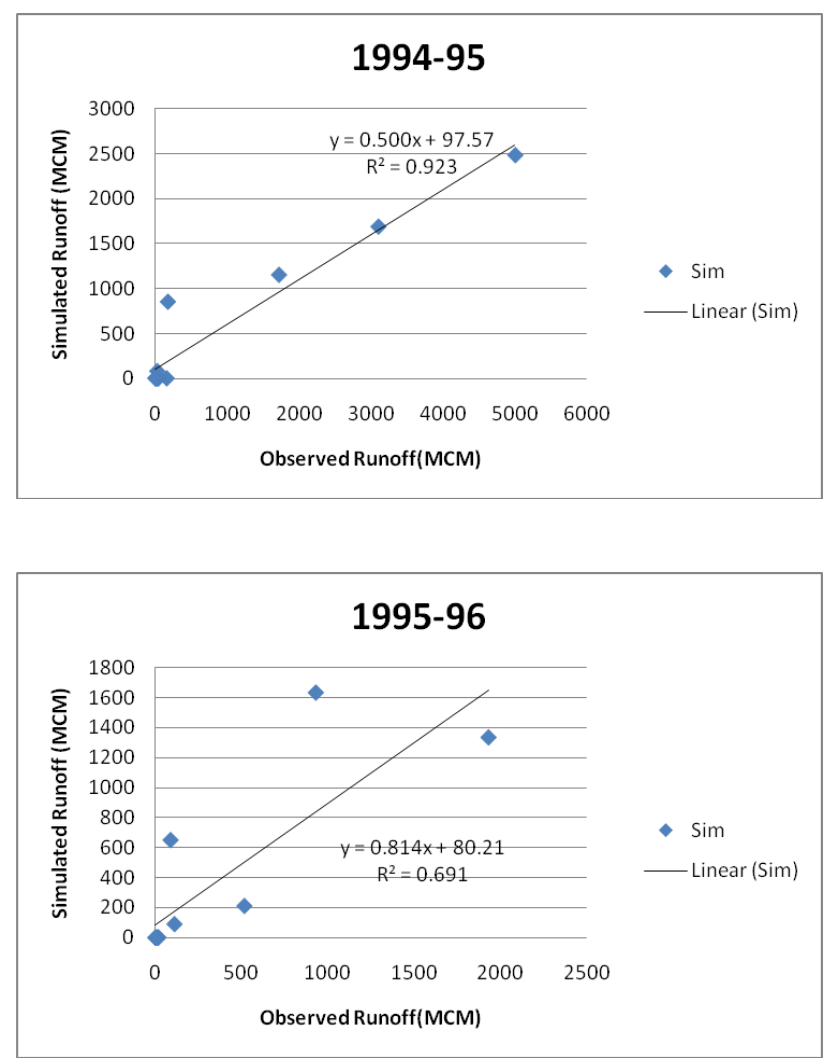

Figure10. Goodness of fit for Observed and Simulated monthly runoff for the period 1992- 1996.

It can be concluded from the Simulation Results of the study the model was simulated the runoff reasonably well from Tapi sub catchment area (Burhanpur watershed).

\section{CONCLUSIONS}

In the present study, SWAT model has been applied to a part of the Upper Tapi basin for the purpose of simulating the rainfall runoff process in the sub-basin. SWAT is a river basin scale, physically based continuous time series model. It requires various parameters and catchment characteristics to perform hydrological modeling. The model has the capability to generate the climatic data through weather generator by defining the various monthly parameters. In the present study, the hydrological modeling is performed using arc SWAT model for the Tapi sub-catchment area. The model uses arc GIS 
environment and calculates the surface runoff at various monitoring points in a catchment. For topographic analysis, the SRTM DEM at $90 \mathrm{~m}$ grid size has been used. The topographic DEM has been resampled to $1000 \mathrm{~m}$ grid size in LCC projection. All other GIS layers, such as soil map, land use map, and slope map have also been processed with the same projection parameters.

ARC GIS has been used to delineate the watershed by defining the threshold value as 10000 ha. A total of 56 sub-basins have been generated with this threshold. Using the land use, soil, and slope maps and their attribute information, multiple HRUs have been generated in each sub-basin. Next, the daily rainfall and temperature data at various gauging sites in the Tapi basin in/around the study area have been input to the model from January, 1992 to December, 1997. Various other data files, such as reservoir characteristics and water use details in the study basin was specified. The model runs were taken with the specified data at daily time step and the output results have been analyzed at monthly time step. The simulated flows at the basin outlet have been compared with the observed flows for four years of record (1992-93 to 1995-96) and the results are encouraging. The coefficient of determination for the monthly runoff was obtained as 0.82, 0.68, 0.92, 0.69 can be considered as a satisfactory value.

\section{ACKNOWLEDGEMENTS (OPTIONAL)}

I would sincerely like to thank Prof. P.K. Joshi Head of the Dept. of Natural Resource, TERI University for a constant source of guidance and inspiration for me throughout the entire study work.

\section{REFERENCES}

1. Arnold, J. G. et al. 2011, 'Soil and Water Assessment Tool Theoretical Documentation-Version-2009', Soil and Water Research Laboratory, Agriculture Research services, Blackland Research Center, Temple, Texas.

2. Arnold, JG et al. 2007, "Soil and Water Assessment Tool User's manual - Version 2005", Soil and Water Research Laboratory, Agriculture Research services, 808 East Blackland Road, Temple, Texas.

3. Goel, M. K. et al. 2008, 'Holistic Evaluation of a Representative Link Development of a Water Availability and Simulation Model', National Institute of Hydrology, roorkee.

4. Jain, SK et al. 2010, 'Simulation of Runoff and Sediment Yield for a Himalayan Watershed Using SWAT model', J. Water Resource and Protection, 2010 pp. 276-281.

5. Khare, D. et al. 2014, 'Hydrological Modeling of Barinallah Watershed Using Arc SWAT model', International Journal of Geology, Earth and Environment Sciences, vol. 4 (1), pp.224235.

6. Maidment, D. R., "Handbook of Hydrology", Editor-inChief, McGRAW-Hill, INC.

7. Narasayya, K et al. 2013, 'Prediction of Storm-Runoff Using Physically Based Hydrological Model for Burhanpur watershed, India', International Journal of Remote Sensing and Geosciences, vol.2, ISSN No.2319-3484.
8. Simic, Z et al. 2009, 'SWAT Based Runoff Modeling in Complex Catchment Areas Theoretical Background and Numerical Procedures', Journal of the Serbian Society for Computational Mechanics, vol.3, pp.38-63.

9. Tripathi, MP et al. 2003, 'Hydrological modeling of a Small Watershed Using Generated Rainfall in the Soil and Water Assessment Tool model, Hydrological process, 18, 1811-1821.

10. Shrivastava et al, 2004, 'hydrological modeling of a small watershed using satellite data and GIS technique', journal of Indian society of Remote sensing, vol. 32, 2004.

11. C. P Lo, Albert K.W.Yeung - "Concepts and Techniques of Geographic Information System" Prentice-Hall of India Private Limited, New Delhi, India 